\title{
Environmental Impacts and Control of Duststorms
}

\author{
Adeeba Al Hurban* \\ Earth \& Environmental Sciences Dept, Faculty of Science, Kuwait University, Kuwait \\ *Corresponding author: Adeeba Al Hurban, Earth \& Environmental Sciences Dept., Faculty of Science, Kuwait University, \\ Kuwait
}

\begin{tabular}{|c|c|}
\hline ARTICLE INFO & ABSTRACT \\
\hline 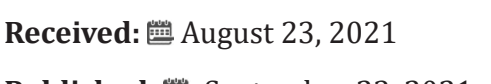 & $\begin{array}{l}\text { Citation: Adeeba Al Hurban. Environmental Impacts and Control of Duststorms. Biomed } \\
\text { J Sci \& Tech Res 39(1)-2021. BJSTR. MS.ID.006230. }\end{array}$ \\
\hline
\end{tabular}

\section{Mini Review}

Duststorms and sandstorms are natural meteorological phenomena and severe weather condition frequently occurring in arid and semi-arid regions mainly during summer season when these regions are subjected to strong winds; and driven by different factors: availability and nature of source sediments, vegetation cover density, prevailing climatic conditions, and the textural characteristics of the surface deposits, environmental, geomorphological and relief variation factors. One of the major terrestrial sources of moving sand worldwide is the Arabian peninsula and Sahara desert, while minor sources come from Iran, Pakistan, and India which deposit dust in the Arabian sea, and from China depositing dust in the Pacific. According to [1], the recent surface deposits are the major source of duststorms in Kuwait which are potentially originated from:

1) Dry sabkhas muddy sediments in the lower Mesopotamian flood plain;

2) Old sandstone, limestone and dolostone sediments exposed in the western desert of Iraq;

3) Dibdibba Formation Paraconglomeratic sediments exposed in southern Iraq and northern Kuwait; and

4) Air locally picked up particles from playa, sabkhas, and finegrained mobile sand.

Duststorms winds have variant local nomenclature. In Sahara desert they are named as Simoom, in some Africa Arabian countries like Egypt, Libya, Sudan, Morocco, and Tunisia, they are named

Khamasine, Ghibli, Haboob, Sahel and Chili, respectively, while in Asian areas like India and the Arabian Gulf region they are named Loo and Shamal or Toze, respectively [2]. A duststorm is distinguished from a sandstorm on the basis of particle size. Dust storms are made up of a multitude of very fine particles while sandstorms have larger particle sizes that range from $.08 \mathrm{~mm}$ to $1 \mathrm{~mm}$ [3]. The fine "dust" particles may be elevated as high as $3 \mathrm{~km}$ or more while the "sand" particles are confined to the lowest $3.5 \mathrm{~m}$, rarely rise more than $15 \mathrm{~m}$ above the ground. The term sandstorm is oftenly used in desert sandstorms context, especially in the Sahara Desert, or places where sand is a more prevalent soil type than dirt or rock, when, in addition to fine particles obscuring visibility, a considerable amount of larger sand particles are blown closer to the surface.

The term duststorm is more likely to be used when finer particles are blown long distances, especially when the duststorm affects urban areas. A sandstorm can transport and carry large volumes of sand unexpectedly. Dust storms can carry large amounts of dust, with the leading edge being composed of a wall of thick dust as much as $1.6 \mathrm{~km}$ (0.99 mi) high. In desert areas, dust and sand storms are most commonly caused by either thunderstorm outflows, or by strong pressure gradients which cause an increase in wind velocity over a wide area. Drought and wind contribute to the emergence of dust storms, as do poor farming (e.g., dryland farming techniques) and grazing practices by exposing the dust and sand to the wind. In addition to the environmental factors including: wind speed, atmospheric stability, source region surface 
characteristics, surface heating, soil moisture, soil type and surface vegetation.

Moreover, in Kuwait human activities in the desert contribute to duststorms occurrence including: extensive motor car movements, extensive urban development, environmentally uncontrolled quarrying activities, and overgrazing by cattle throughout the year In Kuwait duststorms are more frequent during the Spring and Summer due to:

1) The dry fresh (15-24 m/s) northwesterly winds blowing from Iraq and local lands [4];

2) The deserts surrounding Kuwait: Iraqi desert from N-NW and Saudi Arabian from W-S;

3) The loose sediments covering most of the surface area [5].

There are 3 types of dust in Kuwait [6,7]. Duststorms (wind speed $\approx 18$ knots $(33.336 \mathrm{~km} / \mathrm{h})$, horizontal visibility is $<1 \mathrm{~km}$ (if < $200 \mathrm{~m}$ it is called a severe duststorm));2) Rising dust (wind speed is moderate, horizontal visibility is $\geq 1 \mathrm{~km}$ ); and 3) Suspended dust (horizontal visibility is $<1 \mathrm{~km}$ but with moderate wind speed (6-14 $\mathrm{m} / \mathrm{s}$ ) it is in the range of $1-5 \mathrm{~km}$ ). Dust and sandstorms may have impacts in different aspects; physical, environmental, economic, social, human health ... etc.

As physical and environmental sandstorm can possess a huge power that it can move whole sand dunes; Duststorms and suspended dust can reduce visibility to $<200 \mathrm{~m}$; dust may block roads, damage materials and equipment and affect transportation and severely pollute the air. Dust particles can reflect and absorb solar radiation causing radioactive effect as they are tropospheric aerosols a significant component of the earth's climatic system changing climate by their direct radiative scattering and absorption [8], and indirectly by their radiative effects through affecting on clouds microphysics [9] and affecting the processes of atmospheric chemistry. Dust can remarkably affect the soil characteristics, ocean productivity, and air chemistry by influencing the nutrient dynamics and biogeochemical cycling of ecosystems. Economically, duststorms lead to soil loss, which, in turn, will remove the organic matter and nutrient-rich particles reducing the soil fertility and by abrasion they damage the young crop plants and reduce the crop productivity.

Moreover, duststorms reduce visibility affecting aircrafts and road transportation, that would have consequences of financial and human lives loss. Duststorms reduce the amount of sunlight that reaches the surface, and hence cause critical complications on plants photosynthesis and productivity and reduce the livestock forage. Increased clouds of dust and sandstorms can affect the ecosystem stability by increasing the heat blanket effect. Socially wise, by reduction of livestock forage, ecosystem biodiversity and increase hunger, water availability and farmland yields, the land resources will be lost which result in turn will spread poverty, the spread of poverty and hunger will increase, which eventually will result in migration in search of food and relief, and increasing the environmental refugees number that poses pressure on neighborhood areas and leading to enormous social problems.

In relation to public health, duststorms have adverse shorttime impacts on the public health including immediate increased symptoms and worsening of the lung function in individuals with asthma, increased mortality and morbidity long-transported duststorm particles adversely affect the circulatory system. Prolonged and unprotected exposure of the respiratory system in a dust storm can also cause silicosis, which, if left untreated, will lead to asphyxiation; silicosis is an incurable condition that may also lead to lung cancer. It was found by [10] that the concentrations of all pollutants (including Particulate Matter (PM10)) in the ambient air of Kuwait in the residential areas is dependent on the meteorological conditions (PM10 and NOx). It was indicated by [11] that in Kuwait duststorms and fossil fuel combustion strongly contribute to the air pollutants (especially (PM)) which play a significant role in determination the symptoms of Rheumatoid Arthritis (RA) disease and worsening it on overall.

It was stated by [12] that the chronic and long-term exposure to calcite and quartz particles (the major constituents of dustfallout in Kuwait) may produce alkalosis and hypercalcemia and can have potentially serious respiratory effects. There is also the danger of keratoconjunctivitis sicca ("dry eyes") which, in severe cases without immediate and proper treatment, can lead to blindness. There are short-term approaches for dust and sand storm control (e.g., forecasting and early warning) and others are long-term (e.g., source area rehabilitation). In general, dust and sand storms can be controlled by applying different kinds of dust suppressants or wind breakers. Such suppressants may include physical covers, e.g., vegetation, aggregate, mulches or paving; and chemical compounds, e.g., water, either fresh, sea water or even reclaimed, especially on construction sites and unpaved roads; calcium and magnesium chloride and petroleum-based chemicals, which can stabilize the soil by absorbing the moisture from the atmosphere.

This will change the soil surface physical properties as by applying the suppressant the soil particles will be coated and aggregated together becoming heavy to be airborne particles hence unsusceptible for wind erosion. Controlling the movement and sand encroachment by wind can be done by creating tree windbreakers, reducing ground level wind velocity by inserting straw bundles into the sand in a checkerboard pattern, or using creeping plants. Sand or dust encroachment can also be controlled by rehabilitating and improving the land surface by reducing barren land through reforesting and planting degraded land, and improving the environmental capacity of the soil by introducing water-saving and 
water management techniques for the efficient use of water and application of farm animal manure.

\section{References}

1. Khalaf FI, Kadib A, Gharib I, Al Hashash M, AlSaleh S, et al. (Toze) in Kuwait "Mineoralology, granulometry and distribution", ESS-12 final report. Kuwait Institute for Scientific Research (KISR) 2: 221.

2. Olbruck G (1973) Staufalle, der seawart 34: 242-249.

3. Bagnold RA (1941) The physics of blown sand and desert dunes $\left(2^{\text {nd }}\right.$ Edn.)., Edward Aenold, London.

4. Safar MI (1984) Climate and life. General of Civil Aviation, Meteorological Department, Kuwait.

5. Khalaf F, Gharib I, Al Hashash M (1984) Types and characteristics of the recent surface deposits of Kuwait, Arabian Gulf. Journal of Arid Environments 7(1): 9-33.

6. Al Ostad A (1994) A study of the three types of wind-blown dust in Kuwait. Journal of Meteorology, 19(189): 50-155.

ISSN: 2574-1241

DOI: $10.26717 /$ BJSTR.2021.39.006230

Adeeba Al Hurban. Biomed J Sci \& Tech Res

(c) (P) This work is licensed under Creative

Submission Link: https://biomedres.us/submit-manuscript.php
7. Al Ostad A (1998) Aeolian sand and dust transport in southern Kuwait and relationships with climate (Ph. D. thesis). Department of Geography, University of Birmingham, Birmingham, B15 2TT, England.

8. Tegen I, AA Lacis, I Fung (1996) The influence on climate forcing of mineral aerosols from disturbed soils. Nature 380(6573): 419-22.

9. Rosenfeld JE, DB Considine, PE Meade, JT Bacmeister (1997) Stratopheric effects of Mount Pinatubo aerosol studied with a coupled two-dimensional model. Journal of Geophysical Research 102(D3): 3649-70.

10. Al Hurban A, Khader S, Alsaber A, Pan J (2021) Air quality assessment in the State of Kuwait during 2012 to 2017. Atmosphere 12(6): 678.

11. Alsaber A, Pan J, Al-Herz A, Alkandary D, S, Al Hurban A, et al. (2020) Influence of Ambient Air Pollution on Rheumatoid Arthritis Disease Activity Score Index. International Journal Environmental Research and Public Health 17: 416

12. Al Hurban A, Al Ostad A (2010) Textural characteristics of dust fallout and its potential effect on public health in Kuwait City and suburbs. Journal of Environmental Earth Sciences 60: 169-181.

$\begin{array}{ll}\text { BIOMEDICAL } & \text { Assets of Publishing with us } \\ \text { RESEARCHES } & \text { - Global archiving of articles } \\ \text { - Immediate, unrestricted online access }\end{array}$

